\title{
Beach erosion and recovery during consecutive storms at a steep-sloping, meso-tidal beach
}

\author{
Michalis I. Vousdoukas, ${ }^{1,2 *}$ Luis Pedro M. Almeida ${ }^{2}$ and Óscar Ferreira ${ }^{2}$ \\ ${ }^{1}$ Forschungszentrum Küste. Hannover, Germany \\ ${ }^{2}$ CIMA, University of Algarve, Campus de Gambelas, Faro, Portugal
}

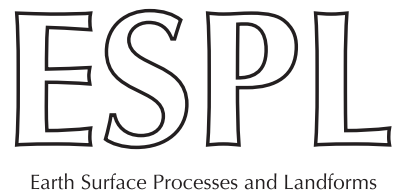

ABSTRACT: This study analyses beach morphological change during six consecutive storms acting on the meso-tidal Faro Beach (south Portugal) between 15 December 2009 and 7 January 2010. Morphological change of the sub-aerial beach profile was monitored through frequent topographic surveys across 11 transects. Measurements of the surf/swash zone dimensions, nearshore bar dynamics, and wave run-up were extracted from time averaged and timestack coastal images, and wave and tidal data were obtained from offshore stations. All the information combined suggests that during consecutive storm events, the antecedent morphological state can initially be the dominant controlling factor of beach response; while the hydrodynamic forcing, and especially the tide and surge levels, become more important during the later stages of a storm period. The dataset also reveals the dynamic nature of steep-sloping beaches, since sub-aerial beach volume reductions up to $30 \mathrm{~m}^{3} / \mathrm{m}$ were followed by intertidal area recovery $(-2<z$ $3 \mathrm{~m}$ ) with rates reaching $\sim 10 \mathrm{~m}^{3} / \mathrm{m}$. However, the observed cumulative dune erosion and profile pivoting imply that storms, even of regular intensity, can have a dramatic impact when they occur in groups. Nearshore bars seemed to respond to temporal scales more related to storm sequences than to individual events. The formation of a prominent crescentic offshore bar at $\sim 200 \mathrm{~m}$ from the shoreline appeared to reverse the previous offshore migration trend of the inner bar, which was gradually shifted close to the seaward swash zone boundary. The partially understood nearshore bar processes appeared to be critical for storm wave attenuation in the surf zone; and were considered mainly responsible for the poor interpretation of the observed beach behaviour on the grounds of standard, non-dimensional, morphological parameters. Copyright @ 2011 John Wiley \& Sons, Ltd.

KEYWORDS: coastal storms; coastal erosion; nearshore bars; beach recovery; storm groups

\section{Introduction}

Storms constitute a significant hazard in coastal regions, triggering geomorphological change and threatening harbour facilities, coastal tourism infrastructure, houses, and even human lives, through storm-surge flooding and wave attack (e.g. Forbes et al., 2004; Lantuit and Pollard, 2008; Seymour et al., 2005). As a result, understanding coastal response to environmental forcing has become an urgent issue, especially given sea-level rise projections and the increasing occupation of coastal areas. In addition, reduced terrestrial sediment supply (e.g. Velegrakis et al., 2008) and infrastructural development of the backshore has reduced the capacity of many beaches and of their associated dune systems to absorb storm energy. For the above reasons, there is a great interest in better understanding the morphological response of coastal areas to storm events.

Storm driven morphological change can be more significant when consecutive storms (storm groups) occur, as they can have a cumulative effect on coastal morphology (Callaghan et al., 2008; Ferreira, 2005). Storm groups can be considered as one 'event' when the recovery time between storms is short and their quick succession can have a large impact on morphology (Lee et al., 1998). For example, Van Enckevort and Ruessink (2003) reported that the temporal scales of nearshore bar position fluctuations were more related to storm sequences than to individual events. However, the probability of storm group occurrence is significantly lower than the one of individual storms, limiting the number of related studies and leading to important knowledge gaps.

Swash represents the main coastal hazard agent, and its intensity is related to the amount of wave energy attenuated during shoaling and breaking that is controlled by beach morphology (e.g. Komar, 1998). Steeper beach slopes tend to allow higher energy levels at the shoreline due to reduced dissipation (e.g. Vousdoukas et al., 2009; Wright and Short, 1984) and to focus wave power at narrower profile sections rather than at gently sloping beaches. As a result, steep beaches are more likely to undergo rapid morphological changes resulting from variations in offshore wave energy level and direction (e.g. Qi et al., 2010). However, most existing studies on morphological impacts of storms are related to dissipative/intermediate beaches (after Wright and Short, 1984) and very few (e.g. Backstrom et al., 2008) involve steep, sandy beaches with beach face slopes exceeding $\tan (\beta)>0 \cdot 10$. The number of previous studies (if any) on the impact of storm groups on such environments is even more limited. 
Given the foregoing context, this paper analyses beach erosion and recovery during consecutive storms acting on the steep-sloping, meso-tidal Faro Beach (south Portugal) between 15 December 2009 and 7 January 2010. The impact of the storm group was monitored through topographic surveys and with a coastal video system which provided information on wave run-up and nearshore bar dynamics. All the available information is combined and thoroughly discussed in an effort to expand our understanding of (i) erosion and recovery processes under storm groups on steep-sloping, dynamic beaches, and of (ii) the relative importance of acting forces, such as offshore wave characteristics, tidal elevation, the grouping of storms, as well as of the morphological feedback on wave attenuation.

\section{Study Area}

Faro Beach is located in the central and eastern areas of the Ancão Peninsula, in the westernmost sector of the Ria Formosa barrier island system (Algarve, south Portugal; see Figure 1). Tides in the area are semi-diurnal, with average ranges of $2.8 \mathrm{~m}$ for spring tides and $1.3 \mathrm{~m}$ during neap tides, although a maximum range of $3.5 \mathrm{~m}$ can be reached. Wave climate in the area is moderate, with an average annual significant offshore wave height $H_{\mathrm{s}}=0.92 \mathrm{~m}$ and average peak wave period $T_{\mathrm{p}}=8.2$ seconds (Costa et al., 2001). Waves approach from the west-southwest (W-SW) and east-southeast (E-SE) for $71 \%$ and $23 \%$ of the time, respectively (Costa et al., 2001). Storms are considered to occur when the significant wave height $\left(H_{\mathrm{s}}\right)$ exceeds $3 \mathrm{~m}$ (Almeida et al., 2011b).

While the eastern sector of Faro Beach is accreting and vegetated foredune development is evident (Almeida et al., 2011a; Ferreira et al., 2006), the central and western parts tend toward erosion, with much of their natural dune ridge having being destroyed and replaced by urban development (Figure 1).
As a result, a part of the ocean front has been artificially stabilized with sea walls, which together with roads and walls are often overwashed during spring tides or under stormy conditions. The area monitored in this study is a coastal stretch of $\sim 100 \mathrm{~m}$ alongshore length, located in the central, steep-sloping part of Faro Beach (Figure 1). Although settlements and various coastal facilities (e.g. car parking, restaurants) can be found behind the beach, a natural dune exists at this area with an average crest elevation $\sim 6 \mathrm{~m}$ above mean sea level (MSL).

Faro Beach is characterized by a steep beach-face, with average slope around $10 \%$, varying from $6 \%$ to $15 \%$ (Vousdoukas et al., 2011c), with a tendency to decrease eastwards along the beach (Ferreira et al., 2006). The western part discussed in the present study has been classified as 'reflective' (see classification of Wright and Short, 1984) by Martins et al. (1996); even though the 'intermediate' class is more appropriate during the energetic winter period (Vousdoukas et al., 2011c). Sediments are medium to very coarse, moderately well sorted sands (see classification of Folk, 1980) with $d_{50} \sim 0.5 \mathrm{~mm}$ and $d_{90} \sim 2 \mathrm{~mm}$.

\section{Materials and Methods}

\section{Wave and tide measurements}

Wave data were provided by a wave buoy deployed offshore from Faro Beach at $93 \mathrm{~m}$ depth (Figure 1a) by the Portuguese Hydrographic Institute (http://www.hidrografico.pt). Tidal data were available from a pressure transducer (Infinity PT, Figure 1b), deployed offshore Faro Beach at $14 \mathrm{~m}$ depth MSL. Wave spectra and statistical wave parameters (e.g. significant wave height and peak wave period) were obtained using standard pressure attenuation correction and zero-crossing techniques. Infragravity and incident frequency band energy contributions were estimated by integrating the spectra energy density considering a cutoff frequency of $0.05 \mathrm{~Hz}$.

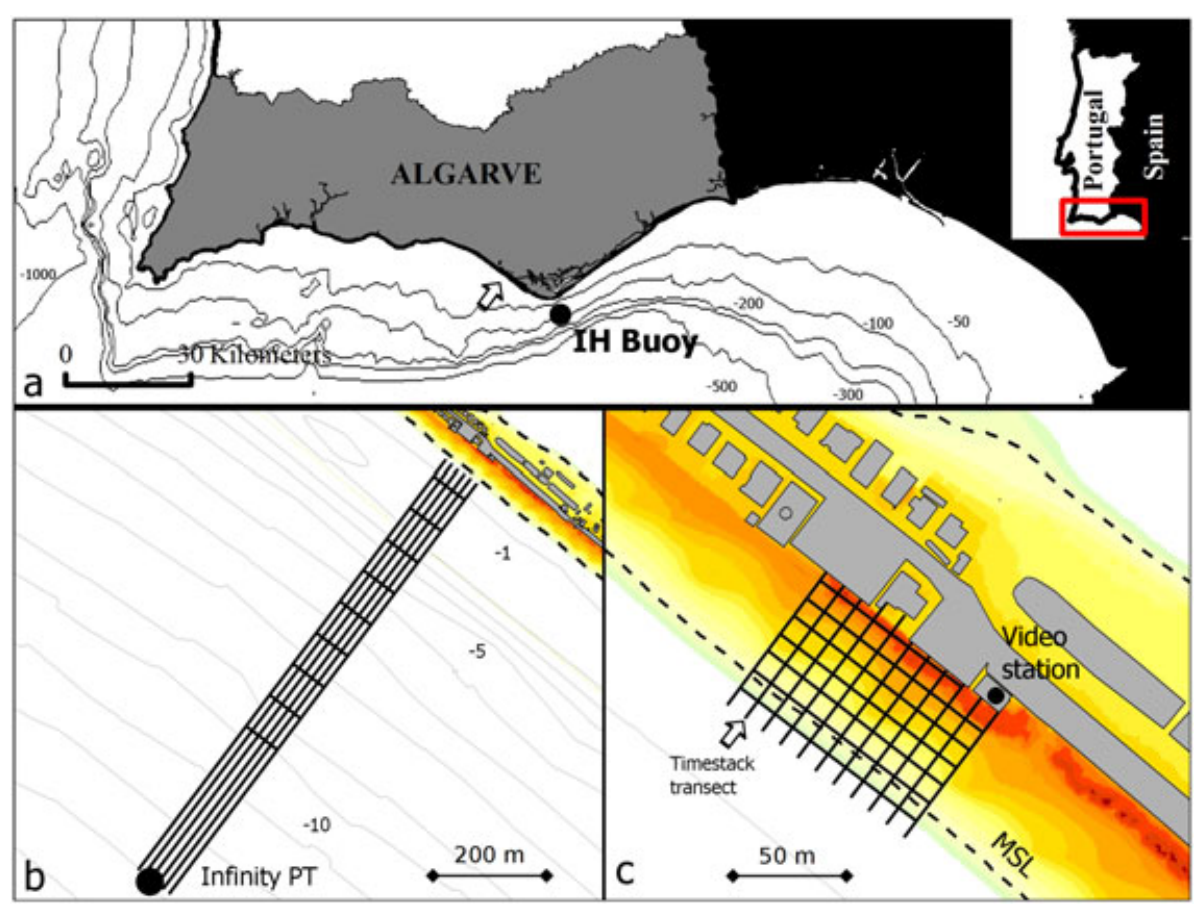

Figure 1. (a) Map of the Algarve region (south Portugal) showing the locations of the study area (arrow) and the IH buoy. (b) Map of Faro Beach, containing LiDAR topographic and bathymetric information and showing the bathymetric survey lines, as well as the location of the pressure transducer (Infinity PT). (c) Zoom-in on the sub-aerial profile section showing the topographic survey grid, the location of the video station, and the crossshore transect along which the swash motion was monitored (Timestack transect). This figure is available in colour online at wileyonlinelibrary.com/journal/espl 


\section{Topographic and bathymetric measurements}

Topographic data were obtained along 11 cross-shore transects with $10 \mathrm{~m}$ alongshore spacing (Figure 1c) using a real-timekinematic global positioning system (RTK-GPS). Seventeen surveys took place during low tide over a period of 20 days, with an estimated accuracy of $\sim 5 \mathrm{~cm}$ for both vertical and horizontal dimensions. Pre- and post-storm bathymetric surveys took place on 15 December 2009 and 8 January 2010, respectively, using two RTK-GPS for geo-location and an ecosounder (ODOM CV100) for depth measurements. The estimated accuracy is around $1 \mathrm{~m}$ for horizontal positioning and $20 \mathrm{~cm}$ for vertical levelling, and the surveys covered four cross-shore transects with $30 \mathrm{~m}$ alongshore spacing (Figure 1b).

All topo-bathymetric data were initially acquired in Datum 73 (EPSG:27493) coordinate system and were subsequently rotated so that the $x$ - and $y$-axes corresponded to cross-shore and alongshore dimensions, respectively. The rotation angle was $39^{\circ}$ anti-clockwise around the origin of the new coordinate system: $[x, y]=[12255,-295575]$ in Datum 73 . Grids were generated from each topographic survey; from which alongshore mean and standard deviation elevation profiles were estimated. The alongshore averaged elevation profile was considered as the representative one; while the alongshore standard deviation elevation profile was used as a proxy of alongshore morphological variability (e.g. the presence of beach cusps). The bathymetric data were also alongshore averaged and, after being combined with the topographic data, provided full pre- and post-storm beach profiles. Volumetric changes were estimated for the sub-aerial profile, considering sediments lying above MSL. The minimum elevations observed at the alongshore averaged profile during the monitoring period were used as the baseline for sediment volume estimation.

\section{Wave run-up measurements}

A video monitoring station installed on the roof of a building facing Faro Beach was acquiring coastal zone imagery during the monitoring period for 10 minutes every hour during daylight, with an acquisition frequency of $1 \mathrm{~Hz}$. The system consisted of two Mobotix M22, 3.1 megapixel $(2048 \times 1536$ pixel resolution), Internet Protocol (IP) cameras, connected to a personal computer (PC) with permanent internet access. The elevation of the centre of view (COV) was around $20 \mathrm{~m}$ above MSL. The two cameras provided a $\sim 90^{\circ}$ view of the coast westward of the cameras, covering an alongshore length of $500 \mathrm{~m}$, including the area monitored through topographic surveys (Vousdoukas et al., 2011a).

Transformation from image to world coordinates (image georectification) took place applying standard lens distortion correction (Bouguet, 2007) and perspective transformation theory (Hartley and Zisserman, 2006). Timestack images were generated for the hourly sets acquired during those days on which topographic surveys took place (Figure 2). The cross-shore resolution of the processed timestack images was $0.2 \mathrm{~m}$, equal to the minimum pixel footprint along the monitored transect (Vousdoukas et al., 2011c). On three occasions, when no major morphological changes were detected between days, image data from the day following a topographic survey were also used. Therefore, although run-up was not measured every day, the approach used served to diminish geo-locational artefacts on the obtained wave run-up measurements.

All timestack images were processed in an open-access Graphical User Interface (GUI) software (https://sourceforge. net/projects/guitimestack), specially developed on MATLAB@ to extract and process time-series of the cross-shore position
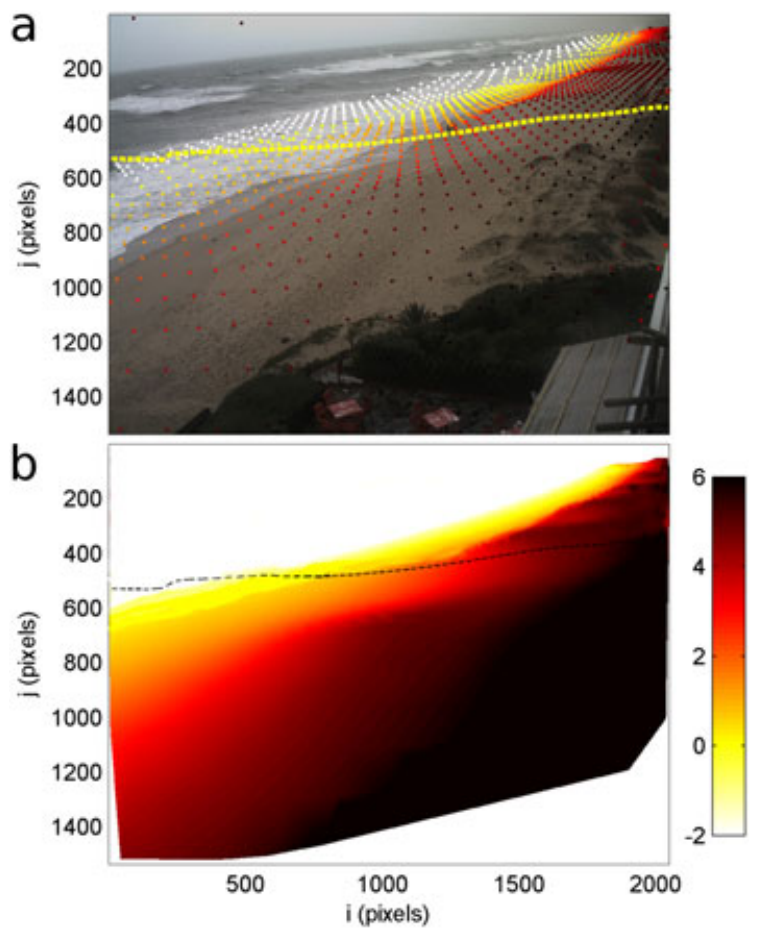

Figure 2. Example of the transformation from world to distorted image coordinates in order to generate timestack images from the raw images (a), considering the irregular beach morphology (b). The dotted line indicates the pixels used for the timestack generation, while colours denote vertical elevation (in metres). This figure is available in colour online at wileyonlinelibrary.com/journal/espl

of the swash extrema (Vousdoukas et al., 2011c). The software allows the extraction of $2 \%$ exceedence $\left(R_{2}\right)$ and maximum wave run-up height values $\left(R_{\max }\right)$, as well as the total run-up elevation $\eta_{\text {total }}(t)$ series and the corresponding spectra. The boundary between the surf and swash zones for each image set was defined as the location of the minimum run-up elevation, while the maximum value was defined as the upper swash zone limit (maximum $\eta_{\text {total }}$ ). All the earlier boundaries were estimated in terms of both elevation and cross-shore distance as measured from the topographic data.

\section{Surf zone and nearshore bars}

Plan-view TIMEX images were generated with a horizontal resolution of $0.25 \mathrm{~m}$, projected onto a horizontal plane with elevation equal to the tidal water level $\eta_{\text {tide }}$ (Vousdoukas et al., 2011a, Vousdoukas et al., 2011b), and were used to extract nearshore bar locations. To reduce geo-locational errors, images acquired during low tide were considered and with sea levels belonging to the first (lower) quartile of each tidal cycle. Pixel intensity profiles were extracted from each image from cross-shore topographic monitoring transects with $5 \mathrm{~m}$ spacing and values were averaged and normalized, to cope with longshore variability. Analysis of the alongshore-averaged and normalized pixel intensity profiles showed that the positions of the nearshore bars were characterized by the presence of 'bell-shaped' peaks (Figure 3b), and could be represented as a function of the sum of a second-order polynomial and $N_{g}$ Gaussian functions (e.g. Aarninkhof and Ruessink, 2004):

$$
I(x)=p_{1}+p_{2} x+p_{3} x^{2}+\sum_{i=1}^{N_{g}} g_{1}^{i} \exp \left(-\left(\frac{x-g_{2}^{i}}{g_{3}^{i}}\right)^{2}\right)
$$

where $x$ is cross-shore distance, $N_{g}$ is the number of Gaussians/ nearshore-bars (two for the present case), $p_{1-3}$ are coefficients 

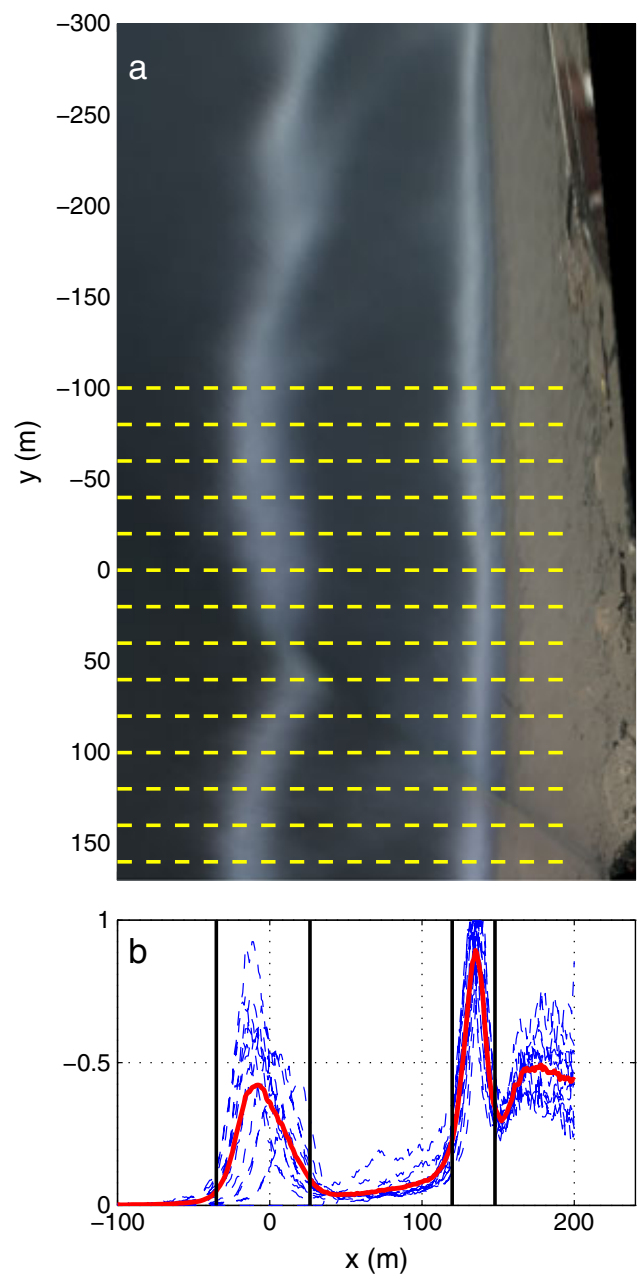

Figure 3. Time averaged (TIMEX) image (a) and resulting identification of the surf limits (vertical lines, b) and the nearshore bar locations (solid line peaks, b); based on the average pixel intensities ( $y$-axis, b) along cross-shore transects in the study area (horizontal lines, a; only five shown for better display). A limited number of transects is shown for better display. This figure is available in colour online at wileyonlinelibrary. com/journal/espl

to parameterize the quadratic function, $g_{j}^{i}$ are the Gaussian parameters ( $\left.j \sim\left[\begin{array}{lll}1 & 2 & 3\end{array}\right]\right)$, for amplitude, centre, and width, respectively), and $l$ is alongshore averaged pixel intensities.

An iterative solver (Lagarias et al., 1998) was applied to estimate the optimal $p$ and $g$ parameters in Equation 1, and the centres of the Gaussians were taken as the locations of the nearshore bars (see Figure 3). Areas where bore-generated turbulence took place (considered to be the surf zone) were identified from the alongshore averaged and normalized pixel intensity profiles when a threshold value of 0.2 was exceeded. Even though the procedure is automatic, user supervision and manual corrections were applied when necessary, so as to identify poor quality images, increase the amount of extracted information, and enhance accuracy.

\section{Results}

\section{Offshore wave conditions}

Five storm events occurred during the monitoring period, according to the significant wave height $\left(H_{\mathrm{s}}=3 \mathrm{~m}\right)$ storm threshold value for the Algarve coast. A two-day period with moderate conditions $\left(H_{\mathrm{s}}\right.$ reaching $\left.2.4 \mathrm{~m}\right)$, starting on 16
December 2009, resulted in significant morphological change and is also considered as an event (Figure 4b, Event A) making up a total of six events labelled from A to $F$ (Figure $4 \mathrm{~b}$ ). The first storm (Event B) occurred on 18 December 2009 with a duration of 12 hours, coinciding with a tidal range of around $2.2 \mathrm{~m}$ (Figure $4 a$ ), followed by $\sim 40$ hours of milder conditions. The values of $H_{\mathrm{s}}$ varied from 2.5 to $3 \mathrm{~m}$ for two days, until 23 December 2009 06:00 when it reached the peak value of $H_{\mathrm{s}}=4.3 \mathrm{~m}$ (Figure $4 \mathrm{~b}$, Event $\mathrm{C}$ ), during almost neap tide with a range $1.5 \mathrm{~m}$. The value of $H_{\mathrm{s}}$ remained above $4 \mathrm{~m}$ for six hours and then fluctuated between 3 and $3.5 \mathrm{~m}$ for two days; this was followed by two periods, one of 44 hours duration with $H_{\mathrm{s}}=2.5 \mathrm{~m}$ and one of 34 hours duration with $H_{\mathrm{s}}$ around $1.4 \mathrm{~m}$.

Wave conditions started to build up again from $H_{\mathrm{s}}=1.5 \mathrm{~m}$ on 28 December 2009 06:00, to $H_{\mathrm{s}}=3.4 \mathrm{~m}$ on 29 December 2009 17:00 and remained at that level for five hours (Event D), during which tidal range was $\sim 2 \mathrm{~m}$. The peak wave period reached also the maximum, for the monitoring period, value of $T_{\mathrm{p}}=15.5 \mathrm{sec}-$ onds. Another high $H_{\mathrm{s}}$ value took place from 30 December 2009 12:00 until 31 December 2009 18:00, during almost spring tide (range $3 \mathrm{~m}$ ), when the $H_{\mathrm{s}}$ reached $3.7 \mathrm{~m}$ (Event E). A mild period of $\sim 3.5$ days followed and a final event occurred on 5 January 2010 with a duration of approximately six hours and a maximum $H_{\mathrm{s}}=4 \mathrm{~m}$ (Event F), during which tidal range was $2.5 \mathrm{~m}$.

During the analysed period, wave direction varied from $210^{\circ}$ to $270^{\circ}$ and was consistently between $230^{\circ}-240^{\circ}$ during the wave height peaks (Figure 4d); slightly deviating from shorenormal conditions $\left(\sim 220^{\circ}\right)$. Similarly, the peak wave period was around 10 seconds, but fluctuated from 5 to 16 seconds (Figure 4c), with the highest values for the monitoring period being observed during Event $\mathrm{D}\left(T_{\mathrm{p}} \sim 15\right.$ seconds) and the lowest ones during Events $B$ and $C$ ( $T_{\mathrm{p}} \sim 11$ seconds).

\section{Swash zone measurements}

Wave run-up measurements were acquired during daylight with the exception of 21-22 December and 1 January, when

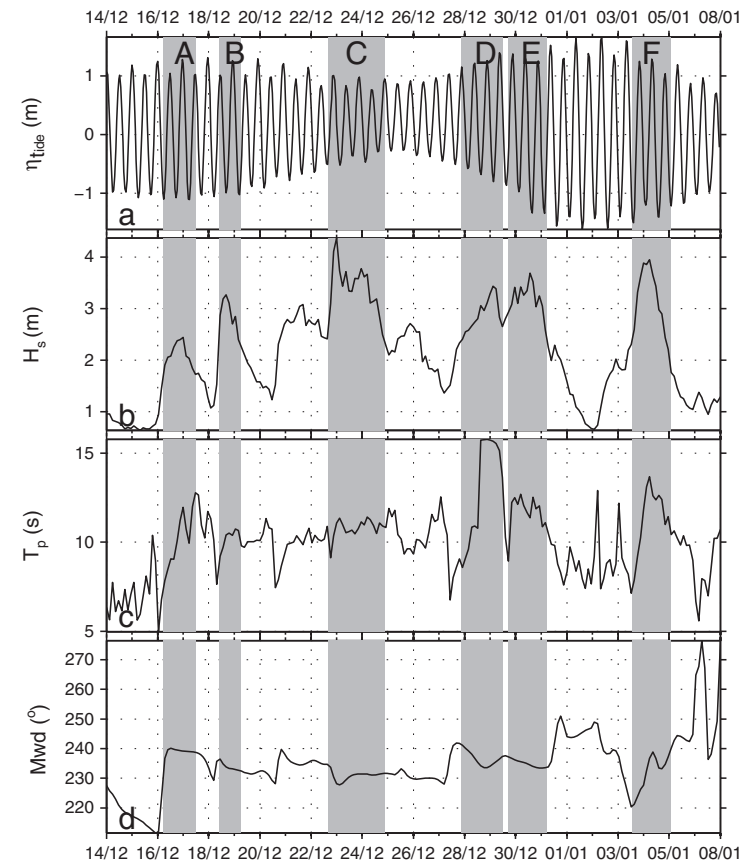

Figure 4. Hydrodynamic conditions during the December 2009January 2010 storms: (a) tidal elevation; (b) significant wave height; (c) peak wave period; (d) mean wave direction. 
the storms resulted in blackouts at the barrier island and stopped temporarily the operation of the video station (see missing data in Figure 5). The $2 \%$ exceedence wave run-up height values $R_{2}$ varied from 0.17 to $2.25 \mathrm{~m}$, around an average value of $R_{2} \sim 1.11 \mathrm{~m}$ (Figure 5a). The average $\eta_{\text {total, } 2 \text { value was }}$ $2.6 \mathrm{~m} \mathrm{MSL}$, while the minimum and maximum values were 0.4 and $5.1 \mathrm{~m} \mathrm{MSL}$, respectively (Figure $5 \mathrm{~b}$ ), with the pre-storm dune foot elevation along the study area measuring $\sim 4 \mathrm{~m} \mathrm{MSL}$ and the dune crest elevation ranging from $\sim 5.7$ to $6.5 \mathrm{~m} \mathrm{MSL}$.

Below-storm-threshold conditions during Event $\mathrm{A}$ resulted in increased values of $R_{2}$ and especially $\eta_{\text {total,2, }}(>4 \mathrm{~m} \mathrm{MSL}$; Figure 5b). Event $B$ was more energetic than Event $A$, but resulted in $R_{2}$ and $\eta_{\text {total, } 2}$ values which were lower than those in Event A, possibly because of the slightly lower tides, but also because of the adapting morphology. Event $\mathrm{C}$ resulted in higher $R_{2}$ values than the previous events (Figure $5 \mathrm{a}$ ), but lower $\eta_{\text {total,2 }}$ as it coincided with neap tides (Figure $5 \mathrm{~b}$ ). The highest $R_{2}$ and $\eta_{\text {total, } 2}$ values, exceeding $2 \mathrm{~m}$ and $5 \mathrm{~m} \mathrm{MSL}$, respectively, were obtained during Events $\mathrm{D}$ and $\mathrm{E}$, with Event $\mathrm{D}$ coinciding with the highest period measured during the monitoring period. The observed $R_{2}$ and $\eta_{\text {total, } 2}$ values during Event $F$ were the lowest ones among the discussed storm events (Figure 5).

The swash zone length ranged from $3.8 \mathrm{~m}$ to $22.6 \mathrm{~m}$ and averaged $12.8 \mathrm{~m}$ for the monitoring period, while it appeared to increase after 18 December and fluctuated less during neap tidal cycles (24-29 December). As expected, the horizontal swash excursion extrema, $x_{\text {swash }}$, followed the trend of the

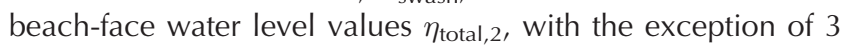
January (Event $F)$ when $x_{\text {swash }}$ reached its peak value $\left(x_{\text {swash }}\right.$ $220 \mathrm{~m})$, which was not the case for $\eta_{\text {total } 2 .}$. The swash zone appeared to become wider $(>17 \mathrm{~m}$ ) when intense wave conditions coincided with rising tides (e.g. $H_{\mathrm{s}}>2.5$ and $\eta_{\text {tide }}>2 \mathrm{~m}$ ), and the most intense regime was observed on the 29 December and 31 December (Events D and E) when the two parameters peaked together.

\section{Wave spectra}

Offshore wave spectra revealed two dominant frequencies at the initiation stage of each storm event, one at $f_{\mathrm{p}}<0.11 / \mathrm{s}$ and another at $f_{\mathrm{p}} \sim 0.231 / \mathrm{s}$, both gradually shifting towards a final peak value of $f_{\mathrm{p}} \sim 0 \cdot 07-0 \cdot 11 / \mathrm{s}$, depending on the particular event. Out of all the events, Event $C$ had the highest total energy,

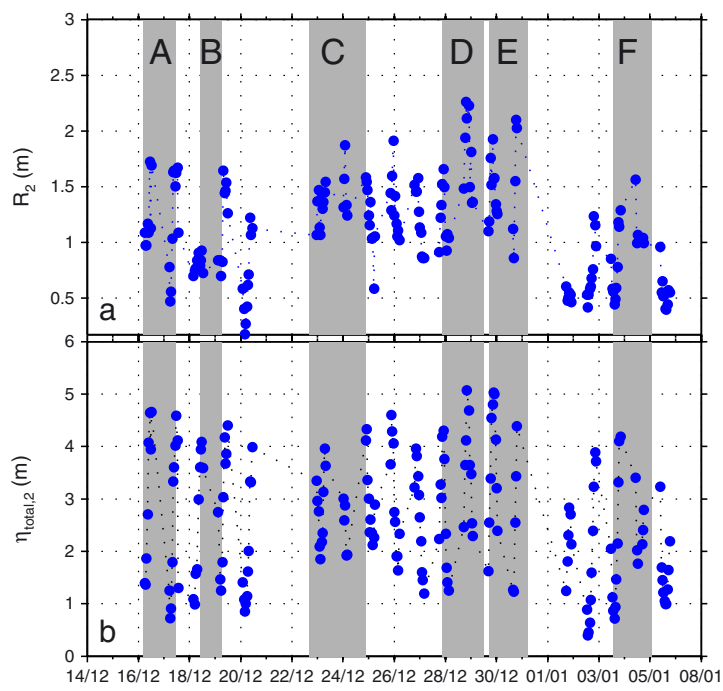

Figure 5. (a) The $2 \%$ exceedence run-up height and (b) $2 \%$ exceedence values of the total run-up elevation (MSL) during the monitoring period. This figure is available in colour online at wileyonlinelibrary.com/journal/espl but had lower infra-gravity energy compared to Events D, E, and F (Figure 6a). Infra-gravity band contributions to the total offshore wave energy ranged from $0.29 \%$ to $5.9 \%$, around an average value of $1.7 \%$; while the swash spectra were dominated by low frequency contributions, especially during storm conditions, with energy contributions varying from $19.04 \%$ to $91.1 \%$, around a mean of $56 \cdot 76 \%$ (Figure 6c). Interestingly, while offshore energy was gradually reduced during the period between Events $C$ and D (Figure 6a), swash energy levels remained relatively high (Figure 6b). The effect of the tidal water-level fluctuations is discerned by the swash spectra energy, and the incident frequency band energy is in phase with $\eta_{\text {tide. Infra-gravity band }}$ contributions in the swash energy were shown to also vary with tidal level, and tended to gradually increase from Event $A$ to Event E (Figure 6c).

\section{Surf zone/nearshore bars}

Analysis of the TIMEX images showed that the outer bar was not well defined during the first several days (16-21 December; Events $\mathrm{A}$ and $\mathrm{B}$ ) and it seemed more like a submerged, terraced feature (Figures $7 \mathrm{a}$ and $7 \mathrm{c}$ ). However, the inner bar was more prominent and detached from the beach (Figures , 7a-7e) and appeared to gradually move offshore until 19 December from $x \sim 140 \mathrm{~m}$ to $x \sim 180 \mathrm{~m}$ (Figure $8 \mathrm{~b}$ ). There was a two-days gap in image acquisition until 23 December, when the inner bar was almost attached to the beach and started to gradually move shoreward, eventually to become more stable, fluctuating around a position $x=170 \mathrm{~m}$ (Figure $8 \mathrm{~b}$ ).

A well defined, crescentic outer bar was visible after Event $C$ (Figures , 7g-7j), especially during low tides and $H_{\mathrm{s}}$ values exceeding $2 \mathrm{~m}$ and appeared to move offshore during the 23 December Event $C$ and again on 4 January (Event $F$; Figure 8b). The peak wave conditions during Event $C$ were also related to

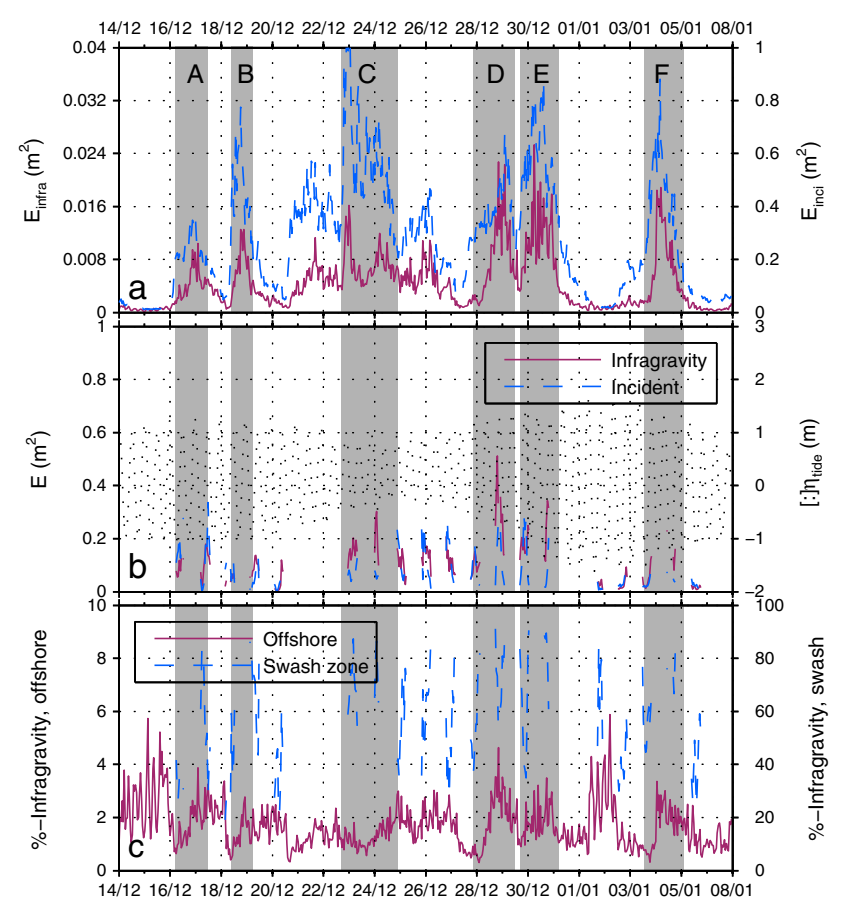

Figure 6. Infra-gravity (solid line, left axis) versus incident band energy (dashed line, right axis) from the offshore wave (a) and swash zone (b) spectra, as well as comparisons of the contribution of the infra-gravity band to the total energy (c). The tidal elevation is also shown on the right axis by a black dashed line in (b). This figure is available in colour online at wileyonlinelibrary.com/journal/espl 

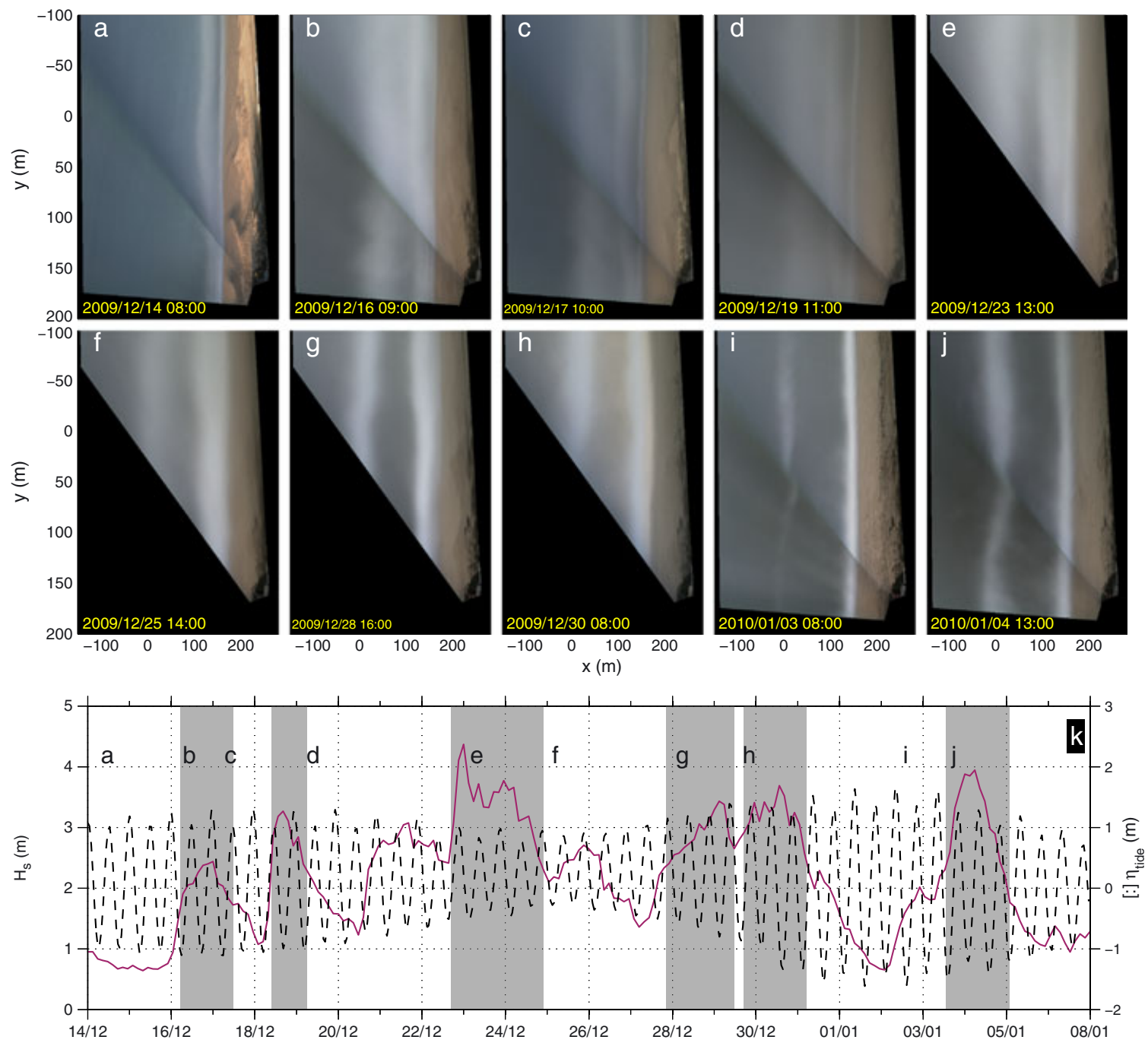

Figure 7. Nearshore bar states during the monitoring period $(\mathrm{a}-\mathrm{j})$, with the letters on the significant wave height plot, indicating the conditions corresponding to each image. This figure is available in colour online at wileyonlinelibrary.com/journal/espl

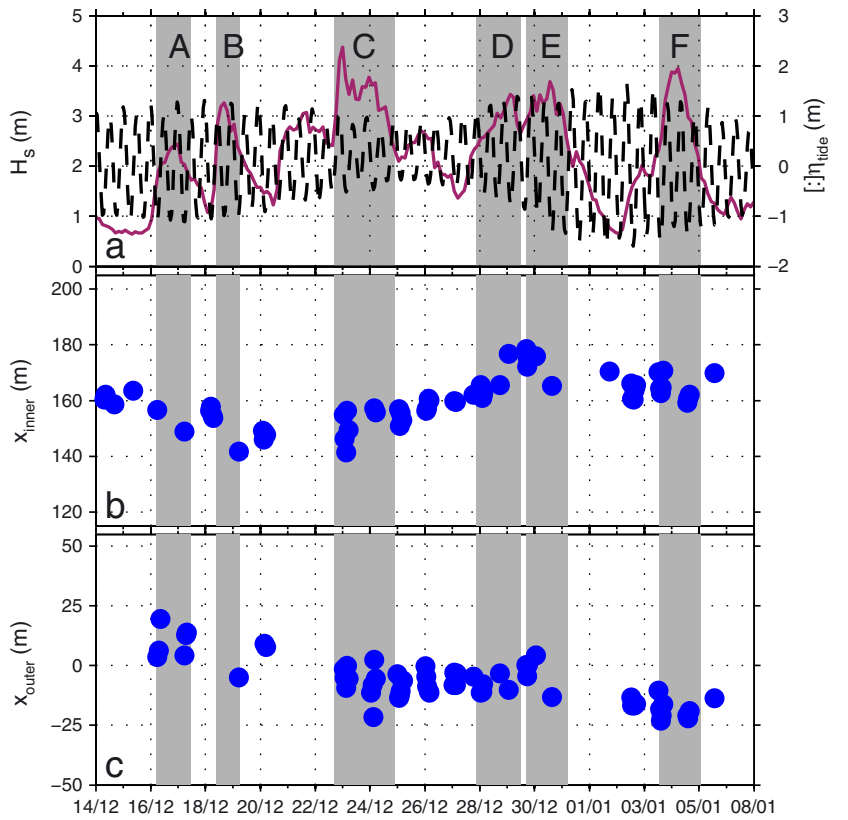

Figure 8. Significant wave height (solid line, left axis) and tidal elevation (dashed line, right axis) (a); positions of the inner bar (b) and outer bar (c), during the monitoring period ( $x$ increases in the shoreward direction). This figure is available in colour online at wileyonlinelibrary. com/journal/espl the maximum surf zone length, discerned from TIMEX images, extending along a profile section of $\sim 200 \mathrm{~m}$ length. After Event $C$ the surf zone during storm conditions became wider, if compared to the previous events during which wave-breaking was taking place along distinct stretches of coast.

\section{Sub-aerial beach profile change}

Event A (16-17 December) was the second longest and most important in terms of sediment loss intensity (see Table I), affecting the profile at elevations up to $4 \mathrm{~m} \mathrm{MSL}$ (close to the dune foot; see Figures $9 \mathrm{~b}$ and 9c), despite the fact that conditions were below the storm threshold value of $H_{\mathrm{s}}=3 \mathrm{~m}$ (Figure 9a). Erosion of both the sub-aerial profile and the intertidal zone resumed during Event B (18-19 December), which also resulted in sediment loss, thus reducing the beach-face slope to a value close to the final value of the monitoring period, $\tan (\beta)<0.08$. Both Events A and B were followed by significant recovery of the sub-aerial profile, in terms of sediment volume, occurring within 24 hours (Figures 9e and 9f). Moreover, waves below the storm threshold during the two-day period between Events $\mathrm{B}$ and $\mathrm{C}$ also resulted in sediment loss at levels similar to Event $\mathrm{B}$, which indicates the rapid morphological response of Faro Beach to changing wave conditions, especially around the intertidal zone. 
Table I. Summary of observed storm events from 15 December 2009 to 8 January 2010.

\begin{tabular}{|c|c|c|c|c|c|c|c|c|c|}
\hline Event & Date & Dur (hour) & $\begin{array}{c}H_{\mathrm{s}, \max } \\
(\mathrm{m})\end{array}$ & $\begin{array}{c}T_{\mathrm{p}, \max } \\
(1 / \mathrm{s})\end{array}$ & $\begin{array}{c}\eta_{\text {tide, max }} \\
\quad(\mathrm{m})\end{array}$ & $\begin{array}{l}R_{2, \max } \\
\quad(\mathrm{m})\end{array}$ & $\begin{array}{l}\eta_{\text {total, max }} \\
(\mathrm{m})\end{array}$ & $\mathrm{d} V\left(\mathrm{~m}^{2}\right)$ & Morphological change \\
\hline A & 16 December 2009 & 40 & $2 \cdot 4$ & $12 \cdot 4$ & $1 \cdot 3$ & $1 \cdot 7$ & $4 \cdot 6$ & -14 & Major beach-face slope change \\
\hline B & 18 December 2009 & 24 & $3 \cdot 3$ & $10 \cdot 9$ & $2 \cdot 0$ & $1 \cdot 6$ & $4 \cdot 1$ & -9 & Beach-face slope reaches 'equilibrium' value \\
\hline C & 23 December 2009 & 51 & $4 \cdot 2$ & $11 \cdot 5$ & $1 \cdot 0$ & 1.9 & 4 & $-2 \cdot 5$ & Outer bar becomes well established \\
\hline $\mathrm{D}$ & 29 December 2009 & 22 & $3 \cdot 3$ & $15 \cdot 9$ & $1 \cdot 1$ & $2 \cdot 3$ & $5 \cdot 1$ & -13 & Major dune erosion \\
\hline$E$ & 30 December 2009 & 34 & $3 \cdot 8$ & $12 \cdot 6$ & $1 \cdot 4$ & $2 \cdot 1$ & 5 & -13 & Dune erosion peak \\
\hline
\end{tabular}

Note: Dur, duration of each event; $H_{\mathrm{s} \text {,max }}$ maximum significant wave height; $T_{\mathrm{p}, \text { max }}, \eta_{\text {tide,max }}$ maximum peak period and offshore sea level of the values corresponding to $H_{\mathrm{s}}>H_{\mathrm{s}, 50} ; R_{2, \text { max }}, \eta_{\text {total,max }}$ maximum $2 \%$ exceedence values of the wave run-up height and beach-face sea level; $\mathrm{d} V$, difference between the post- and pre-storm sediment volumes above MSL (per beach longshore length).

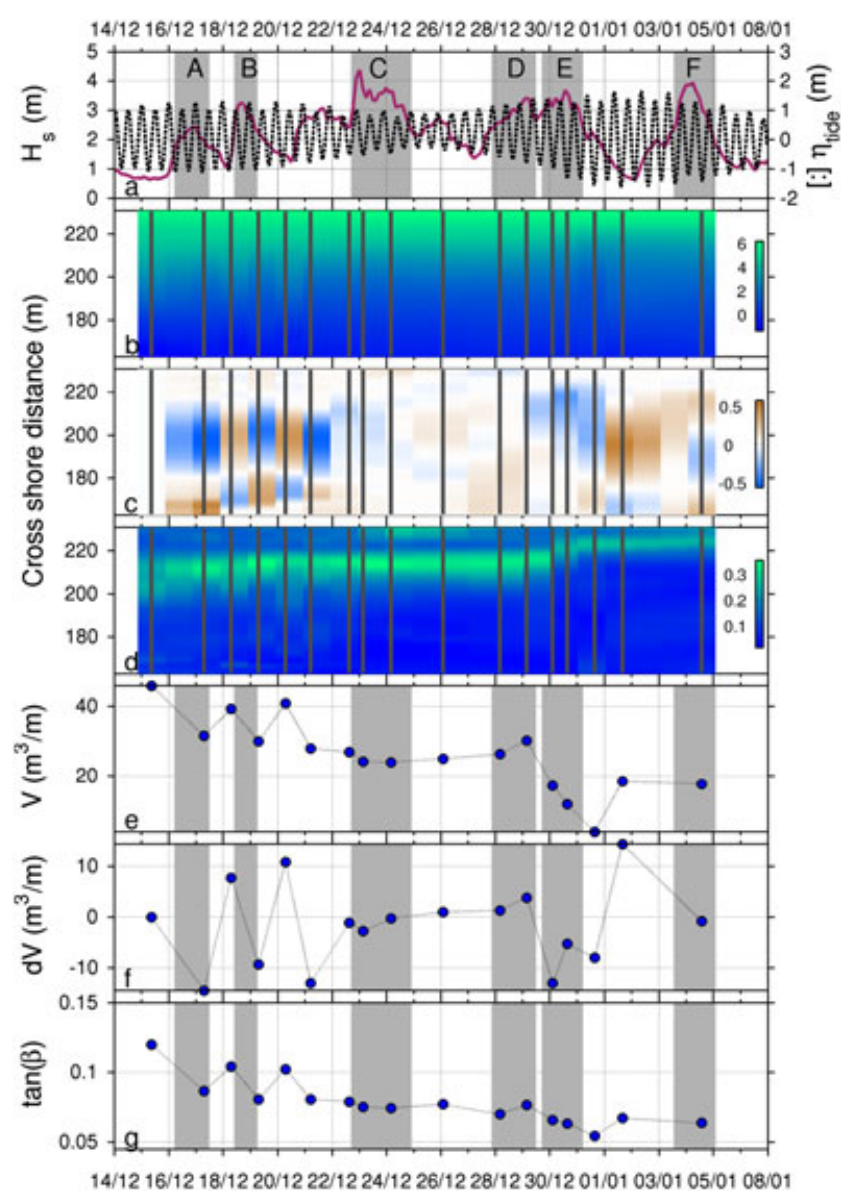

Figure 9. Sub-aerial profile morphological storm impact: significant wave height and MSL (a; left/right axes, solid/dashed lines, respectively); beach profile timestack ( $b$; note that profiles are longshore averaged and colors express elevation in $\mathrm{m}$ ); beach profile change timestack (c; blue/brown for vertical erosion/accretion, in metres); timestack of the alongshore elevation standard deviation profiles (d; colors express alongshore variability); beach sediment volume (above MSL; e) and its variation $(\mathrm{f})$, as well as beach-face slope variation $(\mathrm{g})$. Vertical black lines, where marked, denote the occurrence of topographic surveys; $x$ increases in the shoreward direction in $(b, c, d)$. This figure is available in colour online at wileyonlinelibrary.com/journal/espl

Event C (23-24 December) was the longest and also the most intense in terms of $H_{\mathrm{s}}$ (see Table I), but also coincided with close-to-average wave periods and neap tides. It had a small impact on the sub-aerial profile and dune (Figures 9b and 9c), with the most prominent morphological change being the removal of remaining beach cusp features at $z$ below $4 \mathrm{~m} \mathrm{MSL}$ (see alongshore standard deviation profile, Figure $9 \mathrm{~d}$ ).
The sub-aerial profile recovered during 25-29 December and began to lose sediment only when the wave conditions became more intense, coinciding with almost spring tide. Event D (29 December) had a significant impact on the dune and on the dune-foot, sub-aerial profile section shoreward of $x \sim 195 \mathrm{~m}$ (Figure 9c, see also Table I). Event E (30 December) can barely be separated from Event D, as it occurred the following day, but it had a longer duration (34 hours) and a greater impact, resulting in significant dune erosion and the second highest sediment volume loss observed during the monitoring period (Figure 9e). The sub-aerial profile pivoted around $x \sim 180 \mathrm{~m}$ and sediment from the sub-aerial profile and dune was lost offshore $(180 \mathrm{~m}<$ $x<210 \mathrm{~m}$; see Figure 9c). Total run-up elevations exceeding $5 \mathrm{~m} \mathrm{MSL}$ and swash excursions reaching $x \sim 220 \mathrm{~m}$ affected the dune, which prior to Events $\mathrm{D}$ and $\mathrm{E}$ had been the only beach feature left intact by the storms. Old cusp systems were completely washed out (180m $<x<215 \mathrm{~m}$; Figure 9d) and increased alongshore variability was introduced at the dune $(x \sim 220 \mathrm{~m}$; Figure 9d).

Beach recovery after Events D and E was significant; however, the regaining of sediment was restricted mostly to the intertidal area, and not to the sub-aerial profile. The final storm of 5 January (Event F) affected only that part of the profile below the dune foot and the intertidal zone; the volume variation shown in Figure $9 \mathrm{f}$ is not representative of that event, as the longer intervening time between surveys suggests that recovery after 1 January could have interfered with erosion acting on 5 January.

The beach profile pivoted significantly during the monitoring period with the beach-face slope $(\tan (\beta))$ changing from an initial $\sim 0.12$ to $\sim 0.07$, rapidly during Events $A$ and $B$ and with a slower pace on the following days (Figure 9g). Events D and E resulted in further beach-face slope reduction, a trend which subsequently appeared to reverse to the point where the slope, five days after Event $\mathrm{E}$, had steepened to become equal to that prior to Events $D$ and $E$. The least steep profile during the monitoring period was observed on 31 December, reaching $\tan (\beta)=0.05$.

Events A-F together resulted in significant sub-aerial profile and dune erosion, with sediment being distributed in three main locations: (a) the lower intertidal profile section ( $x \sim 157 \mathrm{~m}$; Figure 10); (b) at $-146<x<-20 \mathrm{~m}$ where off-shore bar migration and build-up was observed; (c) at $-580<x<-$ $450 \mathrm{~m}$, where another smaller longshore bar appeared at higher depth. Apart from the beach-face pivoting linked to erosion, sediment was also removed from the section between the first bar and the intertidal profile $(0<x<140 \mathrm{~m})$.

All six main events are summarized in Table in terms of their duration and the $H_{\mathrm{s}}, R_{2}$, and $\eta_{\text {total, } 2}$ values. The peak period and tidal level values presented correspond to the maximum values occurring when the significant wave height exceeded the event's median value $\left(H_{\mathrm{s}}>H_{\mathrm{s}, 50}\right)$. The differences between 


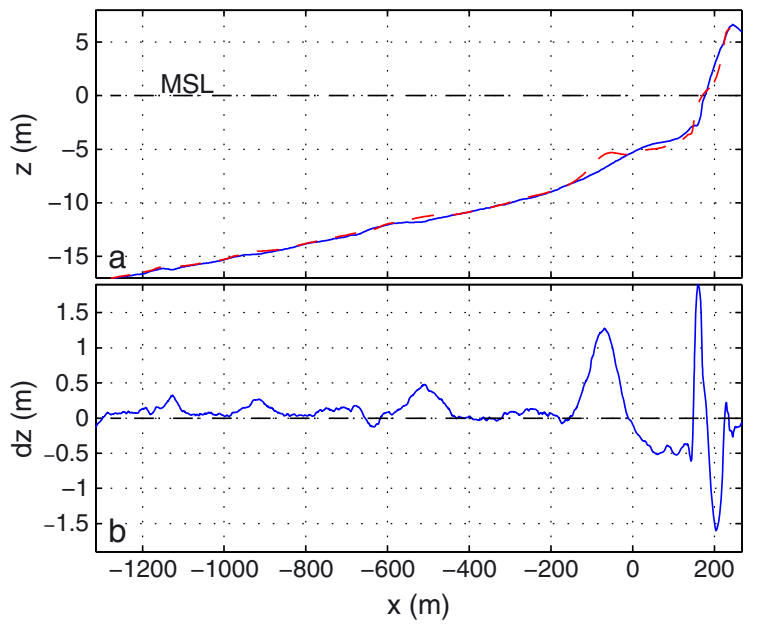

Figure 10. Pre-storm (solid line) and post-storm (dashed line) topobathymetric profiles (a), as well as beach elevation change (b). This figure is available in colour online at wileyonlinelibrary.com/journal/espl

the post- and pre-storm, sub-aerial profile (above MSL) sediment volumes $\mathrm{d} V$ (per alongshore beach length) are also displayed as an indication of storm impact.

\section{Discussion}

\section{Data quality}

In contrast to the sub-aerial beach profile topography, the morphological response along the surf zone was not monitored with 'direct' field measurements, with the exception of the pre- and post-storm bathymetric surveys. This is a standard shortcoming for most similar studies, as data acquisition from submerged beach sections during storm conditions is often practically impossible. In this study, information on the surf zone was provided by non-intrusive video observations; which have been extensively validated in terms of geo-locational errors (e.g. Harley et al., 2011; Vousdoukas et al., 2011a). Regarding the nearshore bar locations, errors were suppressed by considering images geo-rectified at similar elevations (during low tide) and applying careful processing (see earlier); following the methodology described in previous similar studies (e.g. Ruessink et al., 2000; van Enckevort and Ruessink, 2003).

Since video monitoring produced hourly information during daylight, the swash measurements dataset is discontinuous with some data gaps. As a result, the monitoring intensity of the swash zone varies among events and comparisons should be made with caution, especially between the $R_{2}$ and $\eta_{\text {total }}$ values given in Table I. However, the swash zone dataset is dense enough to shed light on the dynamics of the sub-aerial profile dynamics, and complements the other measurements quite well.

\section{Storm groups}

Several previous studies have highlighted storm groups as a cause of increased beach erosion (Lee et al., 1998; Cox and Pirrello, 2001; Ferreira, 2005), although the definition of a storm group appears to vary in existing literature. There are several site-specific criteria to separate consecutive storms, or classify them as part of a group; with the most important being the minimum time between events. The latter varies in literature from 1-2 days (e.g. Dorsh et al., 2008), to more than a month (e.g. Lee et al., 1998). Given that Faro Beach is a dynamic site, the maximum intervening time between individual storms to form a group is correspondingly short and has been considered to be around 30 hours (Ferreira et al., 2009; Almeida et al., 2011b).

Storm groups appear to be more important when individual storms are not long, or powerful enough to lead to a new morphological 'equilibrium' state. Under such conditions, beach recovery rates are also significant, as full recovery between consecutive storms can scale down the group impact to that of individual events (unless a lack of available sediment leads to irreversible changes in sub-aerial profile). For that reason, in previous studies, limited recovery between consecutive events has also been considered as a criterion to define a storm group (e.g. Ferreira, 2005).

The presented topographic data reveal quick recovery along the intertidal zone $(-2<z<3 \mathrm{~m}$ relative to MSL) after Events $A$ and B (16-21 December); and for the same reason Event B can be considered not significant in terms of sub-aerial beach profile erosion (Figure 9). Event $C$ had an even smaller impact on the sub-aerial beach, but significantly affected the surf zone and the nearshore bars. Thus the combination of all data indicates that Events A-E had an accumulated effect on beach morphology, driving several stages of change and can be considered as a storm group. However, it is clear that the definition of a storm group in terms of erosion/sufficient recovery is not straightforward; and also depends on the frame of reference and on the available data.

\section{Nearshore bars dynamics}

After the outer bar became more prominent on 23 December, a gradual shoreward inner-bar migration was discerned, which took place until 1 January (Figure 8b), while the inner bar appeared attached to the coast after 25 December (e.g. Figure 7g). After bar welding was completed, it was difficult to distinguish whether the white patch on the images expressed a bar or a location inside the swash zone. It was decided to classify this feature as 'a bar in a reflective state' (Wright and Short, 1984); which is in agreement with recent studies (e.g. Price and Ruessink, 2011).

Interpreting the behaviour of the inner-bar is not straightforward. Ruessink et al. (2009) reported an 'episodic net offshore migration' of the inner bar on the Gold Coast and gradual merging with the decaying outer bar. That could be the case also in Faro Beach during Events A-C, since (a) the latter events were the first of the winter season and the outer bar appeared to be flat and in a degenerating state (Figure 10a), (b) a trough between the two bars barely existed (e.g. Figure 7b), and (c) the inner bar was migrating offshore (Figure 8b). The above come in agreement with Price and Ruessink (2011) who reported that the inner bar detaches more easily from the beach when the outer bar is flatter (e.g. Figures, 7b-7e).

Gaps in image acquisition did not allow for the verification of whether the inner bar merged with the outer one, even though that could be likely. However, an inner bar was still discernible very close, but still separated, from the 'dry' beach during Event C on 23 December (Figure 7e). As a result, it is also very likely that the inner bar either welded to the beach, or was diffused during Event $\mathrm{C}$ which established the prominent outer bar (Figure $7 f$ ). The latter storm appeared to have re-distributed sediments along the surf zone and introduced a more dissipative beach state. Increased wave attenuation/ breaking along the outer bar may (i) have reduced the wave power near the shore and shifted the 'equilibrium' inner-bar position landward; but may have also (ii) resulted in higher wave set-up heights and thus water levels, again favouring shoreward bar migration, or diffusion. 
The shape of the outer bar remains crescentic during the whole storm progression which comes in agreement to recent studies reporting the presence of crescentic bars, even during energetic, but almost shore normal wave conditions (Ojeda et al., 2011; Price and Ruessink, 2011); which was the case for the discussed storm events. Finally, the presented findings confirm Van Enckevort and Ruessink's (2003) statement that the temporal scales of nearshore bar position fluctuations were more related to storm sequences than to individual events.

\section{Beach morphological response during a storm group}

While the individual events were not exceptional in terms of intensity and were characterized by return periods of less than one year, the average number of storms per year at Faro Beach is slightly higher than five (Almeida et al., 2011b) and as a result the storm group was significant. The latter is also indicated by the measured dune erosion at the monitoring area, as well as visual observations of overwashes and dune crest height reduction at several other locations at Faro Beach. The above changes were irreversible at short to medium term and reduced the site's capacity to absorb storm impact, as the dunes are the main sediment reservoir on the dry beach.

The observations imply that the antecedent morphological conditions were the dominant controlling factor of Faro Beach response to the first two storm events. The steeper beach morphology allows wave impact to focus on the sub-aerial profile and triggers beach erosion and pivoting. From Event $C$ and on, the surf zone morphology appeared to have adapted to a more dissipative state, attenuating efficiently storm wave energy. These interpretations are implied by the minor berm erosion and the nearshore bar dynamics during the energetic Events $C$ and $E$, as well as the tendency to reduced incident-frequency band contributions to the swash spectra after Event $C$ (Figures $6 b$ and 6c).

After 23 December the hydrodynamic forcing and especially the tide and surge levels, appeared to be the dominant factor controlling storm impact. Increased water levels during Events $D$ and $E$ weakened the protection of the sub-aerial profile through wave shoaling/breaking, resulting in landward shoreline migration and higher wave run-up values. The high peak wave period values were also responsible for the increased wave run-up elevations during Event D. All the preceding discussion implies that if events such as D or E had acted on the beach morphology present at the beginning of the monitoring period, the impact would have probably been greater than the one observed between 29 and 31 December. Increased wave energy acting on the beach-face and steeper slopes are expected to have triggered higher run-up heights and potentially overtopping, as also reported by previous studies (Almeida et al., 2011c; Vousdoukas et al., 2011c).

It is interesting to note the frequency and intensity with which erosion/accretion interchange at Faro Beach, even under wave conditions that are moderate for the area (i.e. $H_{\mathrm{s}} \sim 2 \mathrm{~m}$; see Figure 9). Daily volume variations around $10 \mathrm{~m}^{3} / \mathrm{m}$ were quite frequent and were usually coupled with the emergence/ removal of rhythmical features; which can be discerned from the variations of the alongshore standard deviation of the beach elevation (Figure 9d). The combination of the cross-shore and alongshore variations frequently resulted in daily changes of the beach topography locally exceeding $1.5 \mathrm{~m}$ in vertical. Such dynamic behaviour is expected to depend on beach slope, which is likely to control the morphological change for a given amount of transported sediment (e.g. Qi et al., 2010). As a result, sites similar to Faro Beach demand more intensive/ frequent field monitoring to follow the rate of morphological change, as well as to quantify and filter the beach response during the most frequent, but less significant events. The present findings also show that longer-term monitoring which would cover more storms and longer post-storm recovery phases is necessary for a better interpretation of the processes and for precise evaluation of the driving forces (among others, waves, tidal range, wind, cross-shore versus longshore transport).

The preceding discussion highlights the complexity of beach morphological response under storm groups and reveals possible challenges for the modelling and forecasting of both morphological change and storm hazard (e.g. flooding, overtopping). Comparisons of the non-dimensional sediment fall velocity $(\Omega)$ with the volumetric change showed that intense erosion was observed for values of the range $3.5<\Omega<6$ (Figure 11), however the estimated values indicate that $\Omega$ cannot be used for reliable predictions of erosion/accretion. Testing of other standard morphological parameters, like the surf similarity parameter (Battjes, 1974), or the surf-scaling parameter (Guza and Inman, 1975), resulted in an even poorer performance of the interpretation/relation of observed beach behaviour (i.e. volumetric change, contour retreat).

In terms of numerical modelling, assessing the impact of storm groups is also a very challenging task, since (a) it requires profile recovery estimations regarding which current state-ofthe-art numerical models have limited success, and (b) it involves predictions related to longer morphological periods, which introduce increased uncertainty and prohibitively long computational times. However, the present observations come in agreement with the 'equilibrium profile' concept and as a result, they support recent statistical simulation efforts like the one of Callaghan et al. (2008). However, the latter approach is based on the Kriebel and Dean (1993) beach erosion/ accretion model, which does not take into account nearshore bar dynamics, which are shown to be important for the amount of wave energy reaching the sub-aerial profile.

Finally, a proposed conceptual model of the morphological response of steep sloping beaches under consecutive storm events (storm groups) would include the following stages (see also Figure 12):

(a) A rapid beach profile pivoting along the section above MSL during initial storm group stages (Figure 12a).

(b) Further beach erosion/pivoting and transition towards a more dissipative beach state, as the group continues and storm energy and water (surge) level build up (see also Figure 12b).

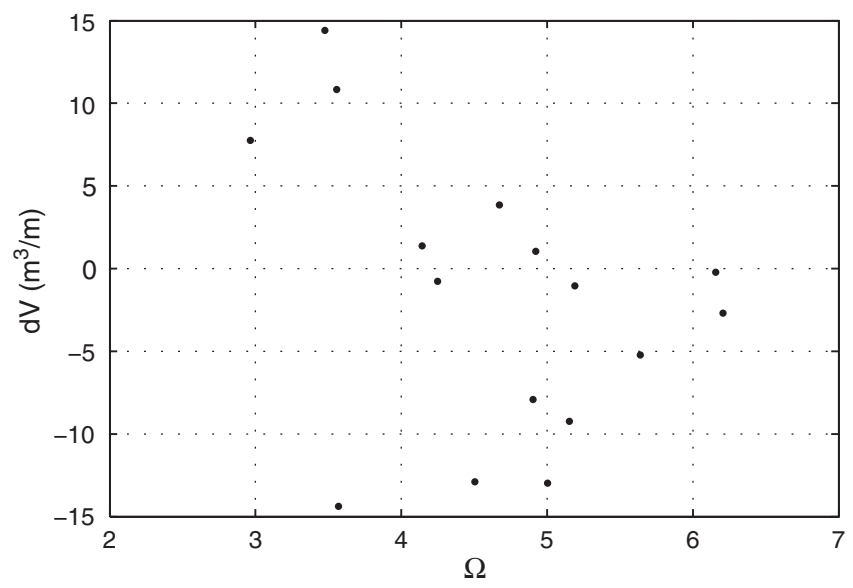

Figure 11. Volumetric change along the sub-aerial profile $( \pm$, for accretion/erosion) versus the non-dimensional fall velocity $\Omega$ (mean values for the period between topographic surveys). 


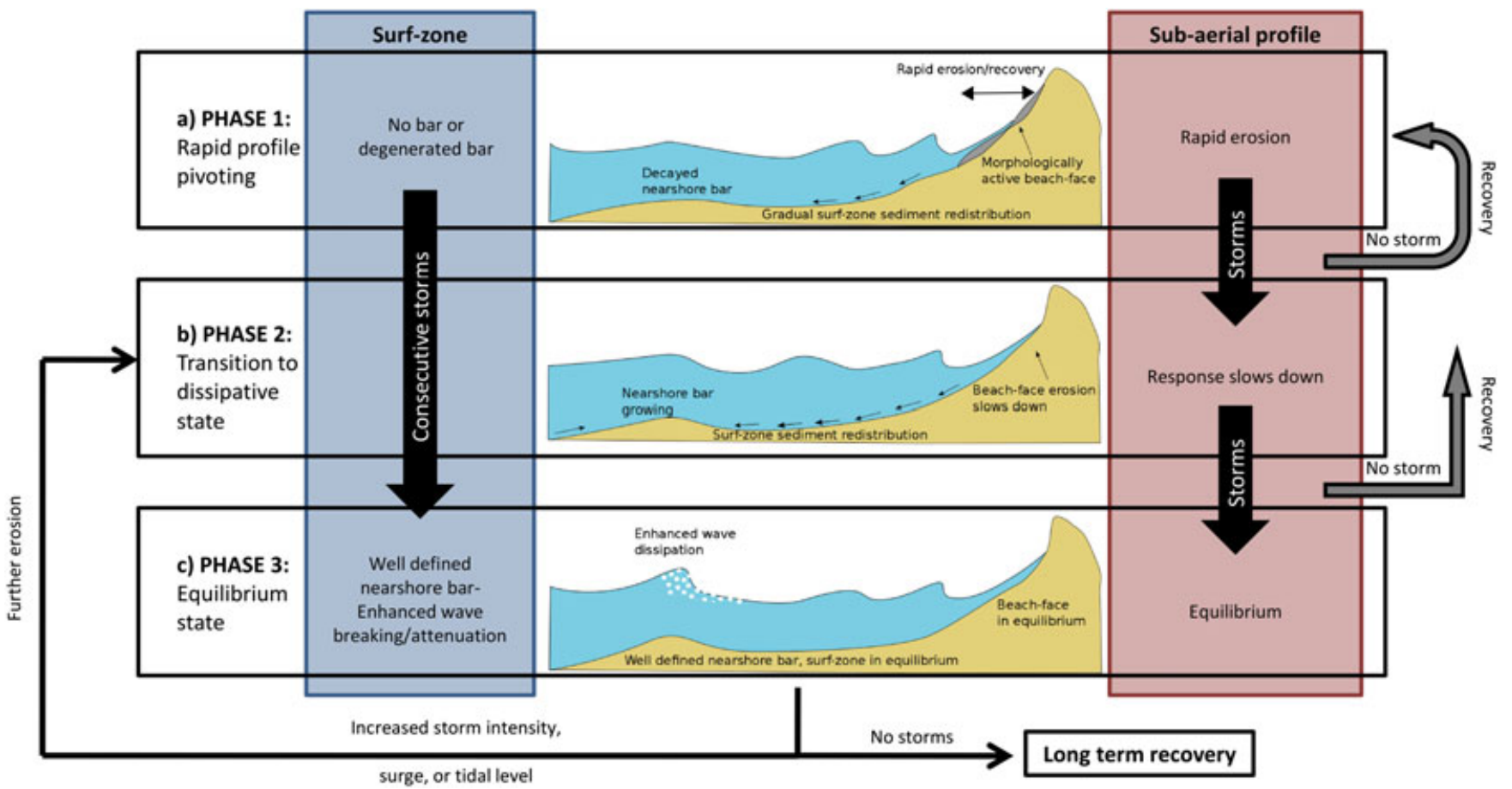

Figure 12. Conceptual model describing beach morphological evolution phases of steep-sloping beaches during consecutive storms: (a) beach-face shows rapid erosion/recovery; (b) the morphological change at the (eroded) sub-aerial beach decelerates and adaptation of the surf-zone bathymetry becomes more important; (c) the beach reaches equilibrium, becomes more resilient to wave forcing and is vulnerable mostly to increased mean water levels. This figure is available in colour online at wileyonlinelibrary.com/journal/espl

(c) If the group duration allows, the sub-aerial profile is the first to achieve equilibrium and morphological change is restricted to the lower (submerged) profile, where most wave attenuation takes place (see also Figure 12b).

(d) The entire profile reaches an equilibrium state and additional erosion occurs only if storm intensity and/or water levels exceed precedent conditions (see also Figure 12c).

(e) The rate and extent of the above progression depend on the hydrodynamic forcing and on the recovery rates between storm events.

\section{Conclusions}

The study set out to analyse the morphodynamic changes and inter-storm recovery during consecutive storm events, for a steep sloping beach at Faro, Portugal. Morphological changes, nearshore bar dynamics, wave run-up measurements, along and offshore wave and tidal data over a monitoring period of 24 days are discussed.

Among the six observed events, the first two resulted in cumulative sub-aerial profile erosion, pivoting, and volume reduction of around $20 \mathrm{~m}^{3} / \mathrm{m}$; while the third one introduced a prominent crescentic nearshore outer bar. The fourth and fifth events, characterized by peak wave periods $T_{p}>14$ seconds, coincided with the highest observed water level values, triggered dune erosion, and resulted in sediment volume reduction of almost $30 \mathrm{~m}^{3} / \mathrm{m}$.

The observed morphological changes suggest that during consecutive storm events, the antecedent morphological state can initially be the dominant controlling factor of beach response; while the hydrodynamic forcing, and especially the tide and surge levels, control storm impact during the later storms.

Beach recovery around the intertidal area $(-2<z<3 \mathrm{~m})$ was found to be active with rates reaching $\sim 10 \mathrm{~m}^{3} / \mathrm{m}$, but recovery did not maintain pace with storm frequency and, therefore, accumulative erosion was observed during the monitoring period. The above implies that storms, even of regular intensity, can have a dramatic impact when they occur in groups.

The temporal scales of nearshore bar position fluctuations were more related to storm sequences than to individual events. The formation of a prominent crescentic offshore bar at $\sim 200 \mathrm{~m}$ from the shore appeared to reverse the previous offshore migration trend of the inner bar, which was gradually shifted close to the seaward swash zone boundary.

The findings allow a conceptual model to be proposed of the morphological response of steep-sloping, meso-tidal beaches to consecutive storm events (storm groups), featuring a multi-stage morphodynamic progression from an initial state to equilibrium, the pace and extent of which is dependent on hydrodynamic forcing, storm time-spacing, and inter-storm recovery rates.

Acknowledgements — The authors gratefully acknowledge the European Community Seventh Framework Programme funding under the research project MICORE (grant agreement No. 202798). The authors are indebted to the Restaurant 'Paquete' for allowing us to deploy the cameras on their rooftop and for supplying electric power and space for our equipment. Dr Andre Pacheco is also acknowledged for his critical contribution to the field surveys and the two anonymous reviewers for their constructive comments.

\section{References}

Aarninkhof SGJ, Ruessink BG. 2004. Video observations and model predictions of depth-induced wave dissipation. IEEE Transactions on Geoscience and Remote Sensing 42: 2612- 2622.

Almeida LP, Ferreira Ó, Pacheco A. 2011a. Thresholds for morphological changes on an exposed sandy beach as a function of wave height. Earth Surface Processes and Landforms 36: 523-532.

Almeida LP, Ferreira Ó, Vousdoukas M, Dodet G. 2011b. Historical variation and trends in storminess along the Portuguese south coast. Natural Hazards and Earth System Sciences 11: 2407-2417. 
Almeida LP, Vousdoukas MI, Ferreira Ó, Rodrigues BA, Matias A. 2011c. Thresholds for storm impacts on an exposed sandy coastal area in southern Portugal. Geomorphology. DOI. 10.1016/j.geomorph.2011.04.047

Backstrom JT, Jackson DWT, Cooper JAG, Malvarez GC. 2008. Stormdriven shoreface morphodynamics on a low-wave energy delta: the role of nearshore topography and shoreline orientation. Journal of Coastal Research 24: 1379-1387.

Battjes JA. 1974. Surf similarity. In 14th Conference on Coastal Engineering. American Society of Civil Engineers (ASCE): Reston, VA; 466-480.

Bouguet J-Y. 2007. Camera Calibration Toolbox for Matlab. http://www. vision.caltech.edu/bouguetj/calib_doc/

Callaghan DP, Nielsen P, Short AD, Ranasinghe R. 2008. Statistical simulation of wave climate and extreme beach erosion. Coastal Engineering 55: 375-390.

Costa M, Silva R, Vitorino J. 2001. Contribuição para o estudo do clima de agitação marítima na costa portuguesa. In 2as Jornadas Portuguesas Engenharia Costeira e Portuária. International Navigation Association PIANC: Sines.

Cox JC, Pirrello MA. 2001. Applying joint probabilities and cumulative effects to estimate storm-erosion and shoreline recession. Shore and Beach 69: 5-7.

Dorsh W, Newland T, Tassone D, Tymons S, Walker D. 2008. A statistical approach to modelling the temporal patterns of ocean storms. Journal of Coastal Research 24: 1430-1438.

Ferreira Ó. 2005. Storm groups versus extreme single storms: predicted erosion and management consequences. Journal of Coastal Reasearch 42: $155-161$

Ferreira Ó, Garcia T, Matias A, Taborda R, Dias JA. 2006. An integrated method for the determination of set-back lines for coastal erosion hazards on sandy shores. Continental Shelf Research 26: 1030-1044.

Ferreira Ó, Vousdoukas MV, Ciavola P. 2009. MICORE Review of Climate Change Impacts on Storm Occurrence (Open access, Deliverable WP1.4). http://micore.eu/area.php?idarea $=28 ; 125$

Folk RL. 1980. Petrology of the Sedimentary Rocks. Hemphill Publishing Company: Austin, TX.

Forbes DL, Parkes GS, Manson GK, Ketch LA. 2004. Storms and shoreline retreat in the southern Gulf of St. Lawrence. Marine Geology 210: 169-204.

Guza RT, Inman DL. 1975. Edge waves and beach cusps. Journal of Geophysical Research 80: 2997-3012.

Harley MD, Turner IL, Short AD, Ranasinghe R. 2011. Assessment and integration of conventional, RTK-GPS and image-derived beach survey methods for daily to decadal coastal monitoring. Coastal Engineering 58: 194-205.

Hartley R, Zisserman A. 2006. Multiple View Geometry in Computer Vision. Cambridge University Press: Cambridge.

Komar PD. 1998. Beach Processes and Sedimentation. Prentice Hall: Englewood Cliffs, NJ.

Kriebel DL, Dean RG. 1993. Convolution method for time dependent beach profile response. Journal of Waterway, Port, Coastal, and Ocean Engineering 119: 204-226.

Lagarias JC, Reeds JA, Wright MH, Wright PE. 1998. Convergence properties of the Nelder-Mead simplex method in low dimensions. SIAM Journal on Optimization 9: 112-147.
Lantuit H, Pollard WH. 2008. Fifty years of coastal erosion and retrogressive thaw slump activity on Herschel Island, southern Beaufort Sea, Yukon Territory, Canada. Geomorphology 95: 84-102.

Lee G-H, Nicholls RJ, Birkemeier WA. 1998. Storm-driven variability of the beach-nearshore profile at Duck, North Carolina, USA, 1981-1991. Marine Geology 148: 163-177.

Martins JT, Ferreira Ó, Ciavola P, Dias JA. 1996. Monitoring of profile changes at Praia de Faro, Algarve: a tool to predict and solve problems. In Partnership in Coastal Zone Management, Taussik J, Michell J (eds). Samara Publishing Limited: Cardigan.

Ojeda E, Guillén J, Ribas F. 2011. Dynamics of single-barred embayed beaches. Marine Geology 280: 76-90. DOI. 10.1016/j.margeo. 2010.12.002

Price TD, Ruessink BG. 2011. State dynamics of a double sandbar system. Continental Shelf Research 31: 659-674. DOI. 10.1016/j. Csr.2010.12.018

Qi H, Cai F, Lei G, Cao H, Shi F. 2010. The response of three main beach types to tropical storms in South China. Marine Geology 275: 244-254.

Ruessink BG, Pape L, Turner IL. 2009. Daily to interannual cross-shore sandbar migration: observations from a multiple sandbar system. Continental Shelf Research 29: 1663-1677. DOI. 10.1016/j. csr.2009.05.011

Ruessink BG, van Enckevort IMJ, Kingston KS, Davidson MA. 2000. Analysis of observed two- and three-dimensional nearshore bar behaviour. Marine Geology 169: 161-183. DOI. 10.1016/s00253227(00)00060-8

Seymour R, Guza RT, O'Reilly W, Elgar S. 2005. Rapid erosion of a small southern California beach fill. Coastal Engineering 52: 151-158.

van Enckevort IMJ, Ruessink BG. 2003. Video observations of nearshore bar behaviour. Part 1: alongshore uniform variability. Continental Shelf Research 23: 501-512. DOI. 10.1016/s0278-4343(02) 00234-0

Velegrakis AF, Vousdoukas MI, Andreadis O, Adamakis G, Pasakalidou E, Meligonitis R, Kokolatos G. 2008. Influence of dams on downstream beaches: Eressos, Lesbos, Eastern Mediterranean. Marine Georesources and Geotechnology 26: 350-371.

Vousdoukas MI, Ferreira PM, Almeida LP, Dodet G, Andriolo U, Psaros F, Taborda R, Silva AN, Ruano AE, Ferreira Ó. 2011a. Performance of intertidal topography video monitoring of a meso-tidal reflective beach in South Portugal. Ocean Dynamics 61: 1521-1540.

Vousdoukas MI, Pennucci G, Holman RA, Conley DC. 2011b. A semi automatic technique for Rapid Environmental Assessment in the coastal zone using Small Unmanned Aerial Vehicles (SUAV). Journal of Coastal Research SI64: 1755-1759.

Vousdoukas MI, Velegrakis AF, Dimou K, Zervakis V, Conley DC. 2009. Wave run-up observations in microtidal, sediment-starved pocket beaches of the Eastern Mediterranean. Journal of Marine Systems 78: S37-S47.

Vousdoukas MI, Wziatek D, Almeida LP. 2011c. Coastal vulnerability assessment based on video wave run-up observations at a meso-tidal, reflective beach. Ocean Dynamics. DOl. 10.1007/s10236-011-0480-x

Wright LD, Short AD. 1984. Morphodynamic variability of surf zones and beaches: a synthesis. Marine Geology 56: 93-118. 